\title{
Factors Influencing Females Work Participation and Work Performance in the Jordanian Public Sector
}

\author{
Bushra K. Mahadin $^{1 *} \quad$ Mottee Al-Shibly $^{2} \quad$ Mahmoud alghizzawi $^{3} \quad$ Ali Ahmad Alkaabi ${ }^{4}$ \\ Hamza Alnawafleh ${ }^{5}$ \\ 1.Faculty of Economics and Management Sciences American University of Madaba- Jordan \\ 2.Faculty of Economics and Management Sciences, Amman Arab University - Jordan \\ 3.Faculty of Economics and Management Sciences, University Sultan Zainal Abidin, Terengganu, Malaysia \\ 4.Faculty of Economics and Management Sciences, University Sains Islam Malaysia, Negeri Sembilan, \\ Malaysia \\ 5.Faculty of Economics and Management Sciences, University of Castilla-La Mancha, Spain
}

\begin{abstract}
With the current development and increasing participation of women in work in developed countries, we find it important to study this issue in Jordan. The objective of this study was to explore the reasons behind the lacking representation of females and their work participation in the Jordanian public sector despite the high percentage of education attainment among them. In general around the world, the increase in women's labor force participation over the past few decades was the main driving force of economic growth. Engaging women into the work sphere as much as possible is considered part of the solution to economic problems and poverty. To achieve this, the researchers employed a comparative and experimental approach to explore the reasons behind the lacking representation of females and their work participation in the Jordanian public sector, based on the outputs and recommendations published from previous studies in this. The results reveal that economic conditions, legal frameworks that cover employment matters, social prejudices and norms towards females work outside of the house, the existence of, religious beliefs are the main specific reasons for women's participation in the labor market. The social view that females are homemakers, mother, and dependents has led to the development of public policies that while aimed at providing protection, have led to the raise in discrimination against them. It is vital to work on building awareness and attitude change about women and men's roles among the general population, in order to facilitate the increase of female work participation.
\end{abstract}

Keywords: Females, Work Participation, Work Performance, Jordan, Public Sector.

DOI: $10.7176 / \mathrm{EJBM} / 12-5-03$

Publication date: February $29^{\text {th }} 2020$

\section{Introduction}

Increased global attention on women's participation in the labor market and its social dimensions has been an incentive to increase studies on the gender and labor participation (Ackah, Ahiadeke and Fenny, 2009; Al-Abdallah and Bataineh, 2018) Where there is greater participation of women in the labor market in developed countries (Ackah, Ahiadeke and Fenny, 2009; Suhaida, Nurulhuda and Faizal, 2014). Certainly the participation of the labor force in the labor market is of great importance in the development of the economic and social aspect. Note that there is an increase in the rate of participation of women in the labor market, but we still note the division of some global markets by gender category where the number of women is few compared to men and can also be observed a large difference in wages between men and women, which indicates that the highest proportion of women participating in the work In the informal market or among the poor, many countries still impose restrictions on women's employment and the development of their potential (Petersson, Mariscal and Ishi, 2017) According to (Women, 1997; The Council of Europe., 2017)A reference to the importance of equality of rights and opportunities between men and women as it is an important principle of human rights and a key condition for lasting development. It is considered both, a human rights principle and a precondition for sustainable, people-centered development. Inequality remains a major obstacle to the development of the human race We still note that inequality between men and women is a major impediment to human development and there is difficulty in applying equality as many women are discriminated against in favor of men in the work areas and this is a negative motivation in the development of their potential (The Council of Europe., 2017). In the past years, developing countries in the Middle East and Africa have increased the participation of women in the labor market, especially in the health and education sector, and the proportion of female students in schools and universities has increased. (Tara, 2012) at present, the proportion of educated women in the Middle East and Africa has increased, but their participation in the labor market and in supporting the economy has not been significantly appreciated the percentage of their participation in these countries, according to the report of the organization (ILO) $26 \%$, but globally reached $56 \%$. The participation rate of men in the labor market reached $76 \%$ in these countries, higher than the world average of $74 \%$ (Al- Ghwell, 2015). The lack of participation of women in the practical sector will have a negative impact on the economic growth of any country, as there will be less productivity and operational 
capabilities, where many scientific researchers have confirmed that economic aid recently working women in support of education and health for their children and this is a catalyst in overcoming Poverty in developing countries. For example, in the UAE, the GDP will rise to $12 \%$ if women participate in the labor market and in Egypt 34\% (Al- Ghwell, 2015)Therefore, the participation of women in the labor sector has not yet been widespread (Ruth Eikhof, 2012). In addition, low-income jobs remain confined to women are (Marlow and McAdam, 2013) Even higher administrative positions also do not include women but are more restricted to men These signs show that there is still a distinction between men and women (Warhurst et al., 2009; Stefanović and Stošić, 2012) In spite of the development of the participation of women in the work sector, we find that we still need to support them, which shows that there is an inequality between men and women, therefore we find the need to deepen more in the social beliefs and skills and abilities possessed by both gender and explain the role of women and men in Countries and Communities (Banyard, 2010; Goodman, Smyth and Banyard, 2010).

\section{Methods}

The paper is divided and organized as follows: In the third section will review the previous studies in this particular area. In the third-one section will deal with Female Work Participation in Jordan and then discuss the results / conclusion section (4-5).

\section{Literature Review}

Managing the role of women in societies varies from country to country, so the study of economic and social factors has been expanded (Powell, 2018)Many researches have confirmed that there is a significant impact of social factors on people (Attanasio, Low and Sánchez-Marcos, 2008; Albanesi and Olivetti, 2016; Habes, Alghizzawi, Salloum, et al., 2018; Habes, Salloum, et al., 2018; Motteh saleh al-shibly, 2018; Rahi, 2018; Alghizzawi, 2019b; Rahi et al., 2019; Salloum, Al-Emran, Habes, et al., 2019) Women's participation in economic activities increases overall productivity (del Mar Alonso-Almeida, 2014)The increasing participation of women in the job enhances the economy and enables women, family, so the participation of women in employment is important (Kabeer, 2005; Bussmann, 2009) Recently, there has been a significant change in the structure of the global workforce with the participation of women in the labor sector. However, according to many indicators, there are still limitations in women's employment by salaries and positions(Mon, 2000; Naqvi, Shahnaz and Arif, 2002; Evers and Sieverding, 2014) according to (McDougall, 1996) indicated that The participation of women in work is largely related to social status, educational level and family size. While There is a relationship between the educational level and the extent of women's participation in the labor market sector, (Yakubu, 2010; Moeeni, 2019)Through modern information technology and communication, it is possible to balance men and women in the work because it will facilitate many tasks (Ruth Eikhof, 2012; Salloum et al., 2017; Alghizzawi, 2019a; Alghizzawi, Habes and Salloum, 2019) The higher the proportion of education, the greater the proportion of women in the labor market (Lechman and Kaur, 2015). Education and wages are factors that affect women to participate in the labor market in addition to social factors and unemployment, so it is necessary to operational programs and financial funding and laws (Sorsa et al., 2015) The likelihood of women's participation increases with the level of education and may decline with family size and marital status. These influences vary by community and country (Hosney, 2016). A study of (Beqa, 2015) in Kosovo found that the labor law and the lack of capital are key factors affecting women's participation in the labor market, and that organizations avoid the extra cost of maternity leave. In Australia, many researchers have found that men are the biggest participants in the labor market and there is a reduction in the role of women (Beqa, 2015) Education is an important factor in women's participation in the labor market (Abraham, Ohemeng and Ohemeng, 2017; Kim and Kim, 2017)Among the laws imposed for equality between men and women include equality in employment (Lai and Sarkar, 2017)In Taiwan, despite many laws to empower women in the labor market, full-time workers have not been activated Act (GEEA), enacted in 2002). When looking comprehensive overview of previous studies, we find that the determinants of women's participation in the labor market and economic activities are affected by different determinants from one society to another and from one country to another, most notably demographic factors and unemployment and GDP.

\subsection{Female Work Participation in Jordan}

Jordanian women are one of the most educated women in the Middle East, where the percentage of female students in universities is higher than that of men. Jordan has $95 \%$ of women writing and reading. However, the percentage of women who work and seek work is only $16 \%$, as $70 \%$ of Jordanian women Have a bachelor's degree and do not work compared to 25\% of men (Schwartz, Mosharafa and Wallace, 2016; Fathi, 2018). Decision makers in Jordan believe that the GDP can rise by $5 \%$ if women participate in the labor market by $24 \%$ as a plan until 2025.(Schwartz, Mosharafa and Wallace, 2016) Studies attribute this lack of participation in the labor market to many reasons, of which we mention the following:

1. Direct and indirect discrimination due to the reproductive role of the females, sexual harassment, female 
victimization (Tesfaye, 2011), There are few job opportunities in the government sector, which has not increased for several years, especially in the educational and health sector (Rich, 2014)

2. There is a difference of skills and scientific specialties with the needs of the labor market required (Bank, 2014)

3. There are no deterrent laws for organizations that distinguish men from women in the labor market in terms of salaries, positions and opportunities (Hosney, 2016).

4. The existence of the "glass ceiling", a term that explains the promotion gap that discriminates against females, where the bias in usually in favor of men rather than of women (Tesfaye, 2011)

5. Economic and infrastructure hurdles, pertaining to the cost of preschools, domestic helpers, low wages, nonexistent public transportation. (Bank, 2014)

6. Certainly, religious and social beliefs about women's work have a significant impact in many countries (Norris, 2009). In Islam, some believe that the work of women should be confined to the home and family, while others believe that women have a great role in supporting society, work and the economy (Caputo et al., 2016)

The Jordanian government did not stand without any action as it has developed policies that help in the equality between men and women on different levels since the nineties, where it worked on several plans, the first of which is the economic development plan, which aimed to prevent discrimination and violence against women (Alnawafleh, 2019; Habes, 2019; Salloum, Al-Emran, Khalaf, et al., 2019)This was followed by the National Plan and the National Committee for Women worked on several development strategies as well (Câmara et al., 2015; Al-Shibly et al., 2019; Habes et al., 2019)The Social norms for Jordanian women are changing, though slowly, over three decades, the role of Jordanian women was restricted to domestic activities, teaching in schools and working in the nursing sector. Recent decades have seen increased women's participation in the labor force, increases in women's life expectancy, improved educational attainment, and decline in fertility rates. Inequities remain in participation in economic and political spheres, as well as in legal rights related to marriage, inheritance, divorce and employment (Câmara et al., 2015; Alghizzawi, Salloum 2018) as well as she shares it with men in the academic and educational sector, (Habes, et al., 2018; Alghizzawi et al., 2019; Habes et al., 2019) therefore the Discrimination between men and women is the main reason for the lack of empowerment of women in Jordan, where there are limitations governing women in the exercise of their lives.(Alghizzawi et al., 2018).

According to the Human Development Report (2018), the calculated gender development index (GDI) for Jordan was $(0.868)$ as shown in the below table 1 . the GDI measure, its measures the extent of discrimination between men and women through three important trends of human development (Jahan and Jespersen, 2016):

I. Health. Measured by life expectancy for men and women

II. Education. It is measured by the average years of schooling for men and women

III. Control of economic resources is measured by the ratio of GNI to men and women

Table 1 Jordan's GDI value and its components

\begin{tabular}{|c|c|c|c|c|c|c|c|c|c|c|c|}
\hline & \multicolumn{2}{|c|}{$\begin{array}{c}\text { Life } \\
\text { Expectancy at } \\
\text { birth }\end{array}$} & \multicolumn{2}{c|}{$\begin{array}{c}\text { Expected } \\
\text { years of } \\
\text { schooling }\end{array}$} & \multicolumn{2}{c|}{$\begin{array}{c}\text { Mean Years of } \\
\text { schooling }\end{array}$} & GNI per capita & \multicolumn{2}{|c|}{ HDI values } & $\begin{array}{c}\text { F-M } \\
\text { ratio }\end{array}$ \\
\cline { 2 - 11 } & $\begin{array}{c}\text { Femal } \\
\text { e }\end{array}$ & $\begin{array}{c}\text { Mal } \\
\text { e }\end{array}$ & $\begin{array}{c}\text { Femal } \\
\text { e }\end{array}$ & $\begin{array}{c}\text { Mal } \\
\text { e }\end{array}$ & $\begin{array}{c}\text { Femal } \\
\text { e }\end{array}$ & $\begin{array}{c}\text { Mal } \\
\text { e }\end{array}$ & $\begin{array}{c}\text { Femal } \\
\text { e }\end{array}$ & Male & $\begin{array}{c}\text { Femal } \\
\text { e }\end{array}$ & $\begin{array}{c}\text { Male } \\
\text { GDI } \\
\text { valu } \\
\text { e }\end{array}$ \\
\hline Jordan & 76.2 & 72.7 & 12.1 & 11.6 & 10.2 & 11.6 & 2,734 & 13,66 & 0.654 & 0.75 & 0.868 \\
4
\end{tabular}

Source: The Human Development Report 2018 (UNDP, 2019)

In 2010 the Gender Inequality Index (GII) was introduced by the Human Development Report, this index reflects gender-based inequalities in three dimensions as follows:

I. Reproductive capacity Maternal mortality and birth rates

II. Empowerment. Proportion of women in education and participation in parliamentary seats

III. Economic Activity Extent of participation of men and women in the labor market

This indicator shows the percentage of missed opportunities in human development due to the existence of discrimination between women and men according to the previous dimensions mentioned. Jordan's index is 0.469 , ranking 113 out of 162 other countries in 2018. Jordan's indicators on the three aspect of GII are shown in the below table 2: 
Table 2 Jordan's GII value and its components

\begin{tabular}{|c|c|c|c|c|c|c|c|c|c|}
\hline & GII & GII & $\begin{array}{c}\text { Maternal } \\
\text { Vortality } \\
\text { Rate }\end{array}$ & $\begin{array}{c}\text { Adolescent } \\
\text { birth rate }\end{array}$ & $\begin{array}{c}\text { Female } \\
\text { seats in } \\
\text { parliament }\end{array}$ & $\begin{array}{c}\text { Population with } \\
\text { at least some } \\
\text { secondary } \\
\text { education }\end{array}$ & $\begin{array}{c}\text { Labor force } \\
\text { participation } \\
\text { rate \% }\end{array}$ \\
\cline { 5 - 9 } & & & & Female & Male & Female & Male \\
\hline
\end{tabular}

Source: The Human Development Report 2018 (UNDP, 2019)

\section{Result / Discussion}

The previous study reveal that economic conditions, legal frameworks that cover employment matters, social prejudices and norms towards females work outside of the house, The existence of what so called "glass ceiling", religious beliefs and attitude towards females work outside of the house, it's the effect on Female work participation and productivity (Jejeebhoy and Sathar, 2001; Naqvi, Shahnaz and Arif, 2002; Dawn Metcalfe and Afanassieva, 2005; Attanasio, 2009; Tesfaye, 2011; Ruth Eikhof, 2012; Evers and Sieverding, 2014; Beqa, 2015; Sorsa et al., 2015; Davis and Maldonado, 2015; Ezzedeen, Budworth and Baker, 2015; Hosney, 2016; Kim and Kim, 2017; Smith McKoy et al., 2018; Habes, Alghizzawi, Salloum, et al., 2018; Campbell, 2019) Women in general have accesses to jobs that offer low wages, and require long and hard working hours, and sometimes do not provide social security. In addition to that the high cost of hiring someone else to help working women with childcare and domestic work creates a barrier for women to seek jobs (Rich, 2014) Furthermore, the social view of women in the Jordanian society still confines them to the reproductive role, which is a dominant idea in the mindset of many employers. Therefore many companies still prefer to employ single young women. This might lead to a situation where many women tend to leave their jobs after marriage; those who remain in the work force are assumed to have high commitment to their careers. Consequently when decisions are made regarding access to training or promotion potential, women are less likely to be considered. Social attitude also affects the decision of the job that they seek, where sometimes the night shift is considered not appropriate for a female. These kinds of factors restrict access to jobs and limit the areas of work. Moreover there is no significant effect of religion on female work participation and productivity (Haghighat, 2005; H'madoun, 2010) Indicating that the Intensity of belief and religious participation employ an opposite effect on the likelihood of employment with the latter being positive and smaller in magnitude than the previous. Research indicates that the Muslim denominations stand out in their negative effect on women's engagement in paid work. While (Nnoromele, 2017) argue the opposite that religion does not influence female labor force participation when controlling for national and environmental cultural factors. Which suggests that a country's institutions, socio-political context, and geographic cultural heritage matter in the way that religiosity is expressed in women's economic participation.

\section{Conclusion}

The main purpose of this study is to shed light on reasons behind the lacking representation of females and their work participation in the Jordanian public sector despite the high percentage of education attainment among them as explained above. The researcher reviewed the previous studies on the subject of the research In general view in the world we find that the participation of women in the work helps in the advancement of the economy and solve many economic problems, but nevertheless the percentage of participation of women at work is low, so it is important to researches more broadly on the factors affecting the decisions of women's employment and has shown many studies on the subject of factors Affecting the process of labor supply and the rules set by organizations such as the impact of life at home and private and social life and labor market policies and level of economic on the decision of women in the job offer and the main objective of this study to explain the reasons for factors affecting The participation of women in the Jordanian public sector The social view that females are homemakers, mother, and dependents has led to the development of public policies that while aimed at providing protection, have led to the raise in discrimination against them. It is vital to work on building awareness and attitude change about women and men's roles among the general population, in order to facilitate the increase of female work participation especially in Developing countries.

\section{References}

Abraham, A. Y., Ohemeng, F. N. A. and Ohemeng, W. (2017) 'Female labour force participation: evidence from Ghana', International Journal of Social Economics. Emerald Publishing Limited, 44(11), pp. 1489-1505.

Ackah, C., Ahiadeke, C. and Fenny, A. P. (2009) 'Determinants of female labour force participation in Ghana', Institute of Statistical, Social and Economic Research, University of Ghana.

Al- Ghwell, H. (2015) Why is Gender Equality Important to the Arab World's Economies.

Al-Abdallah, G. M. and Bataineh, A. Q. (2018) 'Social networking sites and fashion e-purchasing process', Journal of Business and Retail Management Research. The Academy of Business and Retail Management 
(ABRM), 13(2).

Al-Shibly, M. S. et al. (2019) 'The Impact of De-marketing in Reducing Jordanian Youth Consumption of Energy Drinks', in International Conference on Advanced Intelligent Systems and Informatics. Springer, pp. 427437.

Albanesi, S. and Olivetti, C. (2016) 'Gender roles and medical progress', Journal of Political Economy. University of Chicago Press Chicago, IL, 124(3), pp. 650-695.

Alghizzawi, M. et al. (2018) 'The Impact of Smartphone Adoption on Marketing Therapeutic Tourist Sites in Jordan', International Journal of Engineering \& Technology, 7(4.34), pp. 91-96.

Alghizzawi, M. (2019a) 'A survey of the role of social media platforms in viral marketing: The influence of eWOM', International Journal of Information Technology and Language Studies, 3(2).

Alghizzawi, M. et al. (2019) 'The effect of social media usage on students'e-learning acceptance in higher education: A case study from the United Arab Emirates', International Journal of Information Technology and Language Studies, 3(3).

Alghizzawi, M. (2019b) 'The role of digital marketing in consumer behavior: A survey', International Journal of Information Technology and Language Studies, 3(1).

Alghizzawi, M., Habes, M. and Salloum, S. A. (2019) 'The Relationship Between Digital Media and Marketing Medical Tourism Destinations in Jordan: Facebook Perspective', in International Conference on Advanced Intelligent Systems and Informatics. Springer, pp. 438-448.

Alghizzawi, M., Salloum, S. A. and Habes, M. (2018) 'The role of social media in tourism marketing in Jordan', International Journal of Information Technology and Language Studies, 2(3).

Alnawafleh, H., Alghizzawi, M. and Habes, M. (2019) 'The impact of introducing international brands on the development of Jordanian tourism', International Journal of Information Technology and Language Studies, $3(2)$.

Attanasio, O., Low, H. and Sánchez-Marcos, V. (2008) 'Explaining changes in female labor supply in a life-cycle model', American Economic Review, 98(4), pp. 1517-1552.

Attanasio, O. P. (2009) 'Expectations and perceptions in developing countries: their measurement and their use', American Economic Review, 99(2), pp. 87-92.

Bank, T. W. (2014) Women in Jordan - Limited Economic Participation and Continued Inequality.

Banyard, K. (2010) The equality illusion: The truth about women and men today. Faber \& Faber.

Beqa, A. (2015) 'Factors Influencing Gender Gap Participation among the Private and Public Sectors of Kosovo'.

Bussmann, M. (2009) 'The effect of trade openness on women's welfare and work life', World Development. Elsevier, 37(6), pp. 1027-1038.

Câmara, S. M. A. et al. (2015) 'Early maternal age and multiparity are associated to poor physical performance in middle-aged women from Northeast Brazil: a cross-sectional community based study', BMC women's health . BioMed Central, 15(1), p. 56.

Campbell, W. F. S. C. (2019) '11. Women's Employment and Development: A Conceptual Framework Applied to Ghana', Women and work in Africa. Routledge.

Caputo, A. et al. (2016) 'Supporting opportunities for female entrepreneurs in Jordan', International Journal of Entrepreneurship and Small Business. Inderscience, 27(2/3), pp. 384-409.

Davis, D. R. and Maldonado, C. (2015) 'Shattering the glass ceiling: The leadership development of African American women in higher education.', Advancing women in leadership, 35.

Dawn Metcalfe, B. and Afanassieva, M. (2005) 'Gender, work, and equal opportunities in central and eastern Europe', Women in Management Review. Emerald Group Publishing Limited, 20(6), pp. 397-411.

Evers, A. and Sieverding, M. (2014) 'Why do highly qualified women (still) earn less? Gender differences in longterm predictors of career success', Psychology of Women Quarterly. SAGE Publications Sage CA: Los Angeles, CA, 38(1), pp. 93-106.

Ezzedeen, S. R., Budworth, M.-H. and Baker, S. D. (2015) 'The glass ceiling and executive careers: Still an issue for pre-career women', Journal of Career Development. SAGE Publications Sage CA: Los Angeles, CA, 42(5), pp. 355-369.

Fathi, S. (2018) 'The Move towards Gender Equality and Political Participation in Jordan', Oriente Moderno. Brill, 98(2), pp. 203-224.

Goodman, L. A., Smyth, K. F. and Banyard, V. (2010) 'Beyond the 50-minute hour: Increasing control, choice, and connections in the lives of low-income women.', American Journal of Orthopsychiatry. Wiley-Blackwell Publishing Ltd., 80(1), p. 3.

H'madoun, M. (2010) 'Religion and labor force participation of women'.

Habes, M., Alghizzawi, M., Khalaf, R., et al. (2018) 'The Relationship between Social Media and Academic Performance: Facebook Perspective', International Journal of Information Technology and Language Studies, 2(1).

Habes, M., Salloum, S. A., et al. (2018) 'The role of modern media technology in improving collaborative learning 
of students in Jordanian universities', International Journal of Information Technology and Language Studies, 2(3).

Habes, M., Alghizzawi, M., Salloum, S. A., et al. (2018) 'The Use of Mobile Technology in the Marketing of Therapeutic Tourist Sites: A Critical Analysis', International Journal of Information Technology and Language Studies, 2(2).

Habes, M. (2019) 'The influence of personal motivation on using social TV: A Uses and Gratifications Approach', International Journal of Information Technology and Language Studies, 3(1).

Habes, M. et al. (2019) 'The Relation Between Social Media and Students' Academic Performance in Jordan: YouTube Perspective', in International Conference on Advanced Intelligent Systems and Informatics. Springer, pp. 382-392.

Haghighat, E. (2005) 'Neopatriarchy, Islam and female labour force participation: A reconsideration', International Journal of Sociology and Social Policy. Emerald Group Publishing Limited, 25(10/11), pp. 84105.

Hosney, S. H. (2016) Factors influencing female labor force participation in Egypt and Germany: A comparative study. SOEPpapers on Multidisciplinary Panel Data Research.

Jahan, S. and Jespersen, E. (2016) ‘Human Development Report 2016 Team.(2016)', Human Development Report.

Jejeebhoy, S. J. and Sathar, Z. A. (2001) 'Women's autonomy in India and Pakistan: the influence of religion and region', Population and development review. Wiley Online Library, 27(4), pp. 687-712.

Kabeer, N. (2005) 'Gender equality and women's empowerment: A critical analysis of the third millennium development goal 1', Gender \& Development. Taylor \& Francis, 13(1), pp. 13-24.

Kim, H. K. and Kim, Y. H. (2017) 'Work-life conflict of married and childless single female workers', International Journal of Manpower. Emerald Publishing Limited, 38(8), pp. 1157-1170.

Lai, Y.-C. and Sarkar, S. (2017) 'Gender equality legislation and foreign direct investment: Evidence from the labour market of Taiwan ROC', International Journal of Manpower. Emerald Publishing Limited, 38(2), pp. $160-179$.

Lechman, E. and Kaur, H. (2015) 'Economic growth and female labor force participation-verifying the Ufeminization hypothesis. New evidence for 162 countries over the period 1990-2012', New evidence for, 162, pp. 1990-2012.

del Mar Alonso-Almeida, M. (2014) 'Women (and mothers) in the workforce: Worldwide factors', in Women's Studies International Forum. Elsevier, pp. 164-171.

Marlow, S. and McAdam, M. (2013) 'Gender and entrepreneurship: Advancing debate and challenging myths; exploring the mystery of the under-performing female entrepreneur', International Journal of Entrepreneurial Behavior \& Research. Emerald Group Publishing Limited, 19(1), pp. 114-124.

McDougall, M. (1996) 'Equal opportunities versus managing diversity: another challenge for public sector management?', International Journal of Public Sector Management. MCB UP Ltd, 9(5/6), pp. 62-72.

Moeeni, S. (2019) 'Essays on Family Economics and Human Capital Development', in. Arts.

Mon, M. (2000) 'The economic position of women in Burma', Asian studies review. Taylor \& Francis, 24(2), pp. $243-255$.

Motteh saleh al-shibly, B. M. (2018) 'The Influence of eWOM on Facebook on the Jordanian Consumers' Intentions Towards Restaurants', International Journal of Applied Business and Economic Research, 15, p. Number 22 (Part-III).

Naqvi, Z. F., Shahnaz, L. and Arif, G. M. (2002) 'How do women decide to work in Pakistan?[with comments]', The Pakistan development review. JSTOR, pp. 495-513.

Nnoromele, C. H. (2017) 'The Effects of Religion and Patriarchal Norms on Female Labor Force Participation'. Duke University Durham.

Norris, P. (2009) 'Why do Arab states lag the world in gender equality?' HKS Working Paper No. RWP09-020.

Petersson, B., Mariscal, R. and Ishi, K. (2017) Women Are Key for Future Growth: Evidence from Canada. International Monetary Fund.

Powell, G. N. (2018) Women and men in management. Sage Publications.

Rahi, S. (2018) 'EXAMINING THE EFFECTS OF TRAVEL CONSTRAINTS, TOURIST SATISFACTION AND WEBSITE IMAGE ON TOURIST LOYALTY IN DEVELOPING COUNTRIES CONTEXT', Economic and Social Development: Book of Proceedings. Varazdin Development and Entrepreneurship Agency (VADEA), pp. 478-487.

Rahi, S. et al. (2019) 'Integration of UTAUT model in internet banking adoption context', Journal of Research in Interactive Marketing. Emerald Publishing Limited.

Rich, B. (2014) Mortgaging the Earth: World Bank, Environmental Impoverishment and the crisis of development. Routledge.

Ruth Eikhof, D. (2012) 'A double-edged sword: twenty-first century workplace trends and gender equality', Gender in Management: An International Journal. Emerald Group Publishing Limited, 27(1), pp. 7-22. 
Salloum, S. A. et al. (2017) 'Analysis and Classification of Arabic Newspapers' Facebook Pages using Text Mining Techniques', International Journal of Information Technology and Language Studies, 1(2), pp. 817.

Salloum, S. A., Al-Emran, M., Khalaf, R., et al. (2019) 'An Innovative Study of E-Payment Systems Adoption in Higher Education: Theoretical Constructs and Empirical Analysis.', International Journal of Interactive Mobile Technologies, 13(6).

Salloum, S. A., Al-Emran, M., Habes, M., et al. (2019) 'Understanding the Impact of Social Media Practices on E-Learning Systems Acceptance', in International Conference on Advanced Intelligent Systems and Informatics. Springer, pp. 360-369.

Schwartz, J., Mosharafa, E. and Wallace, S. L. (2016) 'Women of Color in Academia and the Influence of Religious Culture on Self-Promotion: A Collaborative Autoethnography'.

Smith McKoy, S. et al. (2018) 'Breaking through the Sexed Glass Ceiling: Women in Academic Leadership Positions'.

Sorsa, P. et al. (2015) 'Determinants of the low female labour force participation in India'. OECD iLibrary.

Stefanović, S. and Stošić, D. (2012) 'Specifics and challenges of female entrepreneurship.', Economic Themes, $50(3)$.

Suhaida, M. A., Nurulhuda, M. S. and Faizal, P. R. M. (2014) 'Internet accessibility and willingness to work among educated women in Malaysia', International Journal of Research in Social Sciences. International Journals of Multidisciplinary Research Academy, 4(4), p. 721.

Tesfaye, Y. (2011) 'The effect of discrimination on job performance and job satisfaction'. Metropolia Ammattikorkeakoulu.

The Council of Europe. (2017) Equality between women and men.

UNDP (2019) Inequalities in Human Development in the 21st Century.

Warhurst, C. et al. (2009) 'Just "mothers really"? Role stretch and low pay amongst female classroom assistants', Work matters. Palgrave Macmillan Basingstoke, pp. 180-196.

Women, U. (1997) Gender Mainstreaming - Concepts and Definitions.

Yakubu, Y. A. (2010) 'Factors influencing female labor force participation in South Africa in 2008', The African Statistical Journal, 11, pp. 85-104. 